\title{
PROMOSI SEKOLAH MELALUI LOMBA CERDAS CERMAT
}

\author{
Rosmita Ambarita,S.Pd,M.Hum \\ Universitas Muslim Nusantara Al-Washliyah
}

\begin{abstract}
ABSTRAK
Pendidikan sangat penting untuk setiap kalangan di berbagai daerah terutama untuk anak kisaran usia 6 - 12 tahun. Begitu jg halnya dengan siswa-siswa SD DARMA BUDI Kecamatan Sidamanik Kabupaten Simalungun dan beberapa siswa SD di sekitarnya. Dari hasil kunjungan dan interview dengan guru dan kepala sekolah bahwa jumlah siswa-siswa yang belajar di SD DARMA BUDI semakin sedikit hal ini di sebabkan minat masyarakat semakin berkurang untuk menyekolahkan anakanya di SD DARMA BUDI.Mereka lebih suka dan tertarik menyekolahkan anaknya di SD NEGRI karena biayanya lebih murah. Hal ini menimbulkan keprihatinan yang cukup besar sehingga diadakanlah sebuah kegiatan sebagai upaya untuk mempromosikan sekolah melalui program kemitraan masyarakat (PKM). Kegiatan PKM ini dilaksanakan bertujuan untuk menarik minat belajar siswa dengan cara mengadakan lomba cerdas cermat sebagai bentuk promosi. Cerdas cermat merupakan teknik pembelajaran yang digunakan untuk dapat meningkatkan keaktifan dan hasil belajar siswa melalui perlombaan. Peserta kegiatan ini diikuti oleh 9 sekolah dengan satu tim terdiri dari 3 siswa. Cerdas cermat terdiri dari 3 babak yaitu babak penyisihan, babak semifinal dan babak final. Pada babak penyisihan diperoleh 5 grup yang kemudian ditandingkan menuju babak semifinal. Selanjutnya dalam babak semifinal diperoleh 4 grup yang bertanding pada babak final untuk memperebutkan kandidat juara. Hasilnya SD YPI Dharma Budi lolos babak penyisihan lanjut ke babak semi final hingga babak final dan memperoleh juara ke II dari 4 grup yang ada di babak final. Hasil kegiatan PKM ini diharapkan dapat menarik minat masyarakat untuk menyekolahkan anak-anaknya di SD YPI Dharma Budi.
\end{abstract}

Kata Kunci: Promosi Sekolah, Lomba Cerdas Cermat, PKM

\begin{abstract}
Education is very important for everyone and also for every various regions especially for children at the age of 6-12 years old. In Sidamanik District Simalungun regency visible from the availability of several elementary schools both public and private. However, the interest of society to send their children to study to elementary school YPI Dharma Budi less than to SD Negeri.The lack of interest of students to study here raises considerable concerns so that an activity is held to promote the school through a community partnership program (PKM) by conducting a quiz contest as a form of promotion. The quiz is a learning technique that is used to improve students' activity and learning outcomes through the contest.Participants of this event followed by 9 schools with one team consisting of 3 students. The quiz consists of 3 rounds namely preliminary round, semifinal round and final round. In the preliminary round obtained 5 groups which then matched to the semifinals. Furthermore, in the semifinal round obtained 4 groups who competed in the final round to win the champion. The result is SD YPI Dharma Budi preliminary round to the semifinals until the final round and won 2 nd place from the 4 groups in the final round. The results of PKM activities are expected to attract society to send their children to study at SD YPI Dharma Budi.
\end{abstract}

Keywords:Selfconfident,,QuizContest,,PKM

\section{PENDAHULUAN}

Desa Sarimatondang Kecamatan Sidamanik Kabupaten Simalungun memiliki beberapa sekolah dasar yang menjadi pilar pendidikan untuk menuntut ilmu. Sekolah dasar di sana berupa SD Negeri maupun SD Swasta. Masalah yang menjadi perhatian di daerah tersebut adalah SD Negeri lebih banyak diminati daripada SD Swasta seperti SD YPI DharmaBudi.Selain permaassalahan diatas berdasarkan hasil kunjungan dan interview dengan guru dan kepala sekolah bahwa siswa kurang memiliki percaya diri. 
Rendahya percaya diri siswa terutama untuk berbicara di depan kelas ataupun menjawab pertnyaan guru secara lisan membuat suasana kelas kurang menarik, hal ini dikarenakan sarana prasarana yang masih minim untuk menunjang proses pembelajaran. Melihat situasi ini salah satu alternatif yang dapat dilakukan untuk meningkatkan minat siswa belajar dan meningkatkan percaya diri adalah dengan mengadakan kegiatan lomba cerdas cermat.

Cerdas cermat merupakan salah satu teknik pembelajaran melalui perlombaan untuk meningkatkan rasa percaya diri siswa. Dengan teknik ini, siswa dapat mengukur kemampuan yang dimilikinya dan saling berkolaborasi dengan teman satu group untuk menjawab pertanyaan secara cepat dan tepat. Hal ini sejalan dengan pendapat Budiana (2013:6) yang mengemukakan bahwa teknik cerdas cermat dapat memberikan kontribusi dalam meningkatkan kemampuan berpendapat siswa dikarenakan teknik ini dapat menggali kemampuan berpikir siswa melalui pertanyaan yang dilontarkan guru dengan memberikan jawaban secara cepat dan tepat.

Teknik ini dapat membuat suasana belajar tidak monoton dan menjadi menyenangkan yang berdampak pada tingginya minat belajar siswa. Membangkitkan percaya diri siswa melalui pendekatan permainan lebih efektif dalam menumbuhkan keingintahuan dan pengalaman dalam bermain cerdas cermat pada lingkungan belajar yang efektif dan memotivasi siswa dalam bentuk permainan (Fauza et al, 2017:22).

Tumbuhnya keberanian dan rasa percaya diri siswa yang dirasakan siswa melalui kegiatan ini akan berdampak pada besarnya perhatian siswa pada SD YPI Dharma Budi. Hal ini sejalan dengan pendapat Alexander (Nurhasanah \& Sobandi, 2016:137) menyatakan bahwa minat timbul secara spontan dengan adanya rasa ingin tahu yang dipengaruhi oleh lingkungan. dengan kata lain, kegiatan lomba yang diadakan memiliki dampak positif terhadap sekolah.

Adapun tujuan dari kegiatan ini adalah membangkitkan minat belajar siswa melalui lomba cerdas cermat.

\section{METODE PELAKSANAAN}

PKM dilaksanakan di SD YPI Dharma Budi Desa Sarimatondang Kecamatan Sidamanik Kabupaten Simalungun dengan melibatkan sembilan sekolah sebagai peserta kegiatan lomba cerdas cermat.

Metode pelaksanaan PKM pada lomba cerdas cermat terdapat tiga babak, yaitu:

1. Babak penyisihan, dimana sembilan sekolah ditandingkan pada tahap ini untuk lanjut ke babak semifinal.

2. Babak semifinal, dimana lima sekolah yang memperoleh skor tertinggi pada babak penyisihan ditandingkan untuk lanjut ke babak terakhir yaitu babak final.

3. Babak final, dimana empat sekolah yang memperoleh nilai tertinggi dari babak semifinal ditandingkan untuk memperebutkan posisi juara.

Lomba cerdas cermat berupa pertanyaan yang di jawab secara lisan dengan tepat dan akurat. Pertanyaan terdiri dari tiga jenis, yaitu:

1. Pertanyaan wajib, diberikan pada tiap regu. 
2. Pertanyaan lemparan, diberikan pada tiap regu namun jika regu tersebut tidak dapat menjawab dalam kurun waktu 5 detik maka akan langsung dilemparkan pada regu yang dapat menjawab.

3. Pertanyaan rebutan, dimana tiap regu memiliki hak yang sama untuk menjawab berdasarkan kecepatan masing-masing regu melambaikkan bendera.

Tiap akhir babak jika ada beberapa regu yang mempunyai skor sama maka akan diberikan tambahan pertanyaan rebutan sebagai alternatif ketentuan penilaian.

\section{HASIL DAN PEMBAHASAN}

\section{Hasil}

Kegiatan lomba cerdas cermat yang diadakan di SD YPI Dharma Budi sukses terlihat dari antusiasnya guru dan siswa mengikuti kegiatan. Lomba diikuti oleh sembilan sekolah.

Pada babak penyisihan diperoleh lima sekolah untuk lanjut pada babak semifinal. Sekolah yang lanjut pada babak semifinal adalah sebagai berikut:

Tabel 1. Nama Sekolah yang Lanjut pada Babak Semifinal

\begin{tabular}{cl}
\hline No & \multicolumn{1}{c}{ Nama Sekolah } \\
\hline $\mathbf{1}$ & SD YPI Dharma Budi \\
\hline $\mathbf{2}$ & SDN 095181 \\
\hline $\mathbf{3}$ & SDN 091409 \\
\hline $\mathbf{4}$ & SDN 091408 \\
\hline $\mathbf{5}$ & SDN 091425 \\
\hline
\end{tabular}

Minat belajar siswa dari lima sekolah yang bertanding sangat tinggi terlihat dari antusias siswa dalam menjawab pertanyaan rebutan. Tiap regu berlomba-lomba untuk memberikan jawaban dengan cepat.

Pada babak final hanya empat sekolah yang bertanding untuk memperebutkan kandidat juara. Pada babak ini minat belajar siswa makin terlihat sangat jelas dengan tiap masing-masing regu berlomba-lomba memperebutkan kesempatan untuk menjawab pertanyaan.

Akhir dari babak ini diperoleh kandidat juara yang menentukan peringkat masing-masing sekolah sebagai pemenang. Adapun peringkat juara pada babak final dapat dilihat pada tabel di bawah ini, yaitu:

Tabel 2. Nama Sekolah, Skor Hasil

Babak Final dan Peringkat Juara

\begin{tabular}{clcc}
\hline No & \multicolumn{1}{c}{$\begin{array}{c}\text { Nama } \\
\text { Sekolah }\end{array}$} & $\begin{array}{c}\text { Skor } \\
\text { Babak } \\
\text { Final }\end{array}$ & $\begin{array}{c}\text { Peringkat } \\
\text { Juara }\end{array}$ \\
\hline $\mathbf{1}$ & SDN 091408 & 200 & Harapan \\
\hline $\mathbf{2}$ & $\begin{array}{l}\text { SD YPI } \\
\text { Dharma Budi }\end{array}$ & 700 & II \\
\hline $\mathbf{3}$ & SDN 095181 & 800 & I \\
\hline $\mathbf{4}$ & SDN 091409 & 600 & III \\
\hline
\end{tabular}

Berdasarkan tabel di atas diketahui bahwa SD YPI Dharma Budi memperoleh skor tertinggi kedua dari empat sekolah yang mengikuti babak final. Dengan hasil ini diharapkan minat belajar siswa untuk bersekolah di SD YPI Dharma juga meningkat.

\section{Pembahasan}

Kegiatan PKM yang dilakukan di Desa Sarimatondang Kecamatan Sidamanik Kabupaten Simalungun tepatnya di SD YPI Dharma Budi terlaksana dengan lancar. Lomba cerdas cermat diikuti 27 peserta dari sembilan sekolah yang mendaftar ulang.

Pada babak penyisihan dibagi menjadi dua kelompok dengan kelompok pertama terdiri dari lima grup dan kelompok kedua terdiri dari empat grup. Kelompok pertama diperoleh tiga grup dengan skor 
tertinggi dan kelompok kedua dipeoleh dua grup dengan skor tertinggi yang kemudian ditandingkan pada babak semi final.

Siswa sangat antusias pada babak semifinal dan final terlihat dari terpacunya motivasi siswa yang berlomba-lomba untuk menjawab pertanyaan pada saat regu yang diberikan pertanyaan tidak dapat menjawab dengan tepat. Hal ini menunjukkan bahwa percaya diri siswa meningkat melalui kegiatan permainan. Dengan demikian, teknik cerdas cermat dapat dijadikan alternatif untuk membangkitkan rasa percaya diri siswa.

\section{KESIMPULAN}

Kegiatan PKM telah berhasil dilaksanakan dengan baik terlihat dari antusias guru dan siswa selama mengikuti lomba cerdas cermat. SD YPI Dharma Budi memperoleh juara II dari empat sekolah yang bertanding pada babak final. Hal ini menunjukkan bahwa minat belajar siswa di sekolah ini sangat tinggi.

Daranai kegiatan PKM yang telah dilaksanakan bahwa masyrakat sekitar banyak yang dating menyaksikan kegiatan Lomba Cerdas Cermat dan sekaligus menjadi sarana promosi sekolah kepada masyrakat sekitar. Dengan demikian, kegiatan ini diharapkan dapat meningkatkan keingintauan masyarakat untuk lebih mengenal tertarik menyekolahkan anak-anaknya di SD YPI Dharma Budi.

\section{REFERENSI}

Budiana, W. 2013. Penggunaan Teknik Cerdas Cermat Untuk Meningkatkan Kemampuan Menyampaikan Pendapat Siswa Kelas VIII 3 SMP Laboraturium Undiksha
Singaraja. Jurnal Pendidikan Bahasa dan Sastra Indonesia Undiksha, 1(5): 1-16.

Fauzan et al. 2017. Aplikasi Cerdas Cermat Online Realtime Untuk Sekolah Dasar. Jurnal Informatika, 14(1):22-27.

Nurhasanah \& Sobandi. 2016. Minat Belajar Sebagai Determinan Hasil Belajar Siswa. Jurnal Pendidikan Manajemen Perkantoran, 1(1):135-1 